\title{
The Prevalence of High Blood Pressure among Marathon Runners during Beirut-Marathon 2014
}

\author{
Souzan Tatari ${ }^{*}$, Rusul Mukhtar1, Hassan Alawieh1, Abdul Rahman Mourad1, \\ Ahmad Araji', Ali El-Sayed', Ahmad Sweid'2, Lea Daher'2, Omar Bou Hamdan², \\ Sola Bahous ${ }^{2}$, Samer Kabbani1 \\ ${ }^{1}$ Rafik Hariri University Hospital, Beirut, Lebanon \\ ${ }^{2}$ University Medical Center-Rizk Hospital, Beirut, Lebanon \\ Email: *tatary_suzan@hotmail.com
}

How to cite this paper: Tatari, S., Mukhtar, R., Alawieh, H., Mourad, A.R., Araji, A., El-Sayed, A., Sweid, A., Daher, L., Hamdan, O.B., Bahous, S. and Kabbani, S. (2017) The Prevalence of High Blood Pressure among Marathon Runners during BeirutMarathon 2014. Open Journal of Epidemiology, 7, 279-284.

https://doi.org/10.4236/ojepi.2017.73022

Received: June 27, 2017

Accepted: August 21, 2017

Published: August 24, 2017

Copyright $\odot 2017$ by authors and Scientific Research Publishing Inc. This work is licensed under the Creative Commons Attribution International License (CC BY 4.0).

http://creativecommons.org/licenses/by/4.0/

\begin{abstract}
Objective: To assess the prevalence of high blood pressure (BP) and cardiovascular risk factors among marathon runners during Beirut-Marathon 2014. Methods: A total of 325 marathon runners were divided into $42 \mathrm{~km}$ and $10 \mathrm{~km}$ groups. They were assessed for cardiovascular risk factors by measuring their BP and answering a questionnaire. The questionnaire composed of 22 questions related to demographic information, risk factors, medical history, family history, medical checkups, use of antihypertensive drugs and definition of hyponatremia. Results: There were 30 runners in the $42 \mathrm{~km}$ group and 295 in the $10 \mathrm{~km}$ group interviewed. The majority of $42 \mathrm{~km}$ runners were males $29(96.7 \%)$ vs. $205(69.5 \%)$ in the $10 \mathrm{~km}$ group, $(\mathrm{P}=0.001)$. The $42 \mathrm{~km}$ group was older than $10 \mathrm{~km}$ group $(47 \pm 13.8$ years vs. $38.5 \pm 14.6$ years; $\mathrm{P}=$ 0.0025). The prevalence of hypertension was $46.7 \%$ in the $42 \mathrm{~km}$ group as compared to $31.2 \%$ in the $10 \mathrm{~km}$ group $(\mathrm{P}=0.08)$. Systolic BP $(\mathrm{SBP})$ was higher in $42 \mathrm{~km}$ group vs. $10 \mathrm{~km}$ group $(143 \pm 22.4 \mathrm{~mm} \mathrm{Hg}$ vs. $129.9 \pm 17.8$ $\mathrm{mm} \mathrm{Hg} ; \mathrm{P}=0.0004)$. The heart rate was lower among $42 \mathrm{~km}$ vs. $10 \mathrm{~km}$ group (71 $\pm 11.1 \mathrm{bpm}$ vs. $84 \pm 16 \mathrm{bpm}$; $\mathrm{P}<0.0001)$. Only $10 \%$ of the runners in both groups reported that they have hypertension (HTN). Conclusion: There is a high prevalence of HTN among marathon runners but minorities were aware that they have hypertension. The $42 \mathrm{~km}$ runners tend to be older with higher systolic blood pressure as compared to the $10 \mathrm{~km}$ runners.
\end{abstract}

\section{Keywords}

Marathon, Blood Pressure, Cardiovascular Risk Factors 


\section{Introduction}

Appropriate aerobic exercise may decrease cardiovascular events, improve diabetes and high blood pressure (BP), and enhance quality of life [1] [2] [3] [4] [5]. Endurance events such as marathon running may also have health benefits; however, the incidences of sudden cardiac deaths that have occurred during marathons imply an element of risk as well [6] [7] [8]. During aerobic exercise, Systolic BP increases as the exercise intensity increases. The heart works harder to pump more oxygenated blood to the muscles. Some people have an abnormal and extremely high spike in BP when they exercise, which is probably an early indicator of poorly controlled BP, therefore a higher risk for future cardiovascular events. Regular physical activity is the first treatment recommended to lower BP and improve cardiovascular health, both in the general population and in those people with hypertension (HTN) [9] [10]. Chest discomfort, irregular heart rhythm, or abnormal breathlessness when exercising can indicate underlying heart disease and should be investigated.

The purpose of this study was conducted to evaluate to the prevalence of HTN and other cardiovascular risk factors among marathon runners in the $42 \mathrm{~km}$ and $10 \mathrm{~km}$ race in Beirut-Lebanon.

\section{Methods}

This is an observational study that was conducted during Beirut-Marathon 2014. Marathon runners who accepted to be examined and answered the questionnaire were included in this study. Runners were excluded if they had incomplete answers to the questionnaire. A total of 400 runners were assessed but due to incomplete information only the data of 325 marathon runners was analyzed. A total of 325 marathon runners were divided according to their running distance into $10 \mathrm{~km}$ and $42 \mathrm{~km}$ groups. A group of cardiologists and nurses distributed in 4 tents were working in parallel for data collection. Each tent contained multiple automatic BP machines, chairs, case report forms (CRF). The marathon runners were assessed for their cardiovascular risks by measuring their $\mathrm{BP}$, heart rate (HR) and answering a questionnaire early in the morning before the start of the marathon. All runners had to sit for 5 min before their BP measurements. The questionnaire composed of 22 questions inquiring about age, gender, weight, height, body mass index (BMI), SBP, DBP, HR, history of cardiovascular events, diabetes mellitus (DM), dyslipidemia, HTN, family history of HTN, and smoking history. Runners were asked whether they had an electrocardiogram (ECG) or not and their knowledge of abnormal BP definition and whether they were treated for HTN. Moreover, runners were asked if they knew what is the definition of hyponatremia. Data was sent to the clinical research unit at Rafik Hariri University Hospital for data entry and analysis.

\section{Statistical Methods}

Data was collected using CRFs. Data entry was done using the excel sheets for 
analysis. All statistical analyses were performed using statistical analysis system (SAS) software (version 9.1; SAS Institute, Cary, NC). Continuous variables were presented as mean and standard deviation (SD) and categorical variables as absolute and relative frequencies (\%). Chi-square test and Student $t$-test were used to compare differences between the groups, as appropriate. A P-value $\leq 0.05$ was considered to be statistically significant.

\section{Results}

Data was collected from 325 marathon runners. Completed data was analyzed for 30 runners in the $42 \mathrm{~km}$ group and 295 runners in the $10 \mathrm{~km}$ group. The majority of $42 \mathrm{~km}$ runners were males' 29 (96.7\%) vs. 205 (69.5\%) in the $10 \mathrm{~km}$ group, (P-0.001). The $42 \mathrm{~km}$ group was older than $10 \mathrm{~km}$ group $47 \pm 13.8$ years vs. $38.5 \pm 14.6$ years in the $10 \mathrm{~km}$ group, (P-0.0025). SBP was higher in $42 \mathrm{~km}$ group vs. $10 \mathrm{~km}$ group $143 \pm 22.4 \mathrm{~mm} \mathrm{Hg}$ vs. $129.9 \pm 17.8 \mathrm{~mm} \mathrm{Hg}$ respectively, (P-0.0004). The resting heart rate was lower among $42 \mathrm{~km}$ group vs. $10 \mathrm{~km}$ group $71 \pm 11.1$ bpm vs. $84 \pm 16$ bpm respectively, $(\mathrm{P}<0.0001)$. The $42 \mathrm{~km}$ runners were healthier, they had less cardiovascular risk factors and they did more regular medical check-ups than the $10 \mathrm{~km}$ runners. Moreover, they knew more about hyponatremia than the $10 \mathrm{~km}$ runners (see Table 1 ).

Table 1. Comparison of characteristics between $42 \mathrm{~km}$ and $10 \mathrm{~km}$ Marathon-Runners.

\begin{tabular}{|c|c|c|c|}
\hline Parameter & $\begin{array}{c}42 \mathrm{~km}(\mathrm{~N}=30) \\
\text { Mean } \pm \mathrm{SD} ; \mathrm{N}(\%)\end{array}$ & $\begin{array}{c}10 \mathrm{~km}(\mathrm{~N}=295) \\
\text { Mean } \pm \mathrm{SD} ; \mathrm{N}(\%)\end{array}$ & P-value \\
\hline Age, years & $47 \pm 13.8$ & $38.5 \pm 14.6$ & 0.0025 \\
\hline Weight, kg & $75.4 \pm 12$ & $74.2 \pm 16.8$ & NS \\
\hline Height, cm & $174.4 \pm 7.4$ & $171.6 \pm 11.6$ & NS \\
\hline BMI & $24.5 \pm 2.9$ & $25.5 \pm 9$ & NS \\
\hline $\mathrm{SBP}, \mathrm{mm} \mathrm{Hg}$ & $143 \pm 22.4$ & $129.9 \pm 17.8$ & 0.0004 \\
\hline $\mathrm{DBP}, \mathrm{mm} \mathrm{Hg}$ & $80.7 \pm 10.3$ & $79.5 \pm 11.5$ & NS \\
\hline HR, b.p.m & $71 \pm 11.1$ & $84 \pm 16$ & $<0.0001$ \\
\hline Male Gender & $29(96.7 \%)$ & $205(69.5 \%)$ & 0.001 \\
\hline Cardiovascular disease & 0 & $5(1.7 \%)$ & NS \\
\hline Smokers & $6(20 \%)$ & $94(31.9 \%)$ & NS \\
\hline $\mathrm{DM}$ & 0 & $16(5.4 \%)$ & NS \\
\hline Dyslipidemia & $1(3.3 \%)$ & $38(12.9 \%)$ & NS \\
\hline HTN & $3(10 \%)$ & $31(10.5 \%)$ & NS \\
\hline Family history of HTN & $11(36.7 \%)$ & $138(46.8 \%)$ & NS \\
\hline BP Checking & $16(53.3 \%)$ & $150(50.8 \%)$ & NS \\
\hline Lipid Checking & $13(43.3 \%)$ & $118(40 \%)$ & NS \\
\hline Sugar Checking & $12(40 \%)$ & $114(38.6 \%)$ & NS \\
\hline Awareness of being hypertensive & $16(53.3 \%)$ & $184(62.4 \%)$ & NS \\
\hline Trusting Automatic BP devices & $20(66.7 \%)$ & $225(76.3 \%)$ & NS \\
\hline Had ECG & $16(53.3 \%)$ & $144(48.8 \%)$ & NS \\
\hline Antihypertensive Medications & $5(16.7 \%)$ & $56(19 \%)$ & NS \\
\hline Definition of Hyponatremia & $6(20 \%)$ & $39(13.2 \%)$ & NS \\
\hline Elevated morning BP & $14(46.7 \%)$ & $92(31.2 \%)$ & 0.08 \\
\hline
\end{tabular}


The prevalence of HTN increases with age for both groups (see Figure 1). According to our data, the prevalence of HTN was greater among males than females in the same age groups. It was shown that $45 \%$ of male runners had HTN between the ages 40 - 49 years whereas only $14 \%$ of the female runners in this age group had HTN. There was $50 \%$ of male runners had HTN between 50 59 years versus $22 \%$ of the female runners and $71.4 \%$ of the male runners had HTN at $\geq 60$ years versus $44 \%$ of the female runners. Moreover, it was observed that almost one third of runners in both groups were not aware that they had elevated BP (36.7\% in $42 \mathrm{~km}$ vs. $20.7 \%$ in the $10 \mathrm{~km}$ ).

\section{Discussion}

This study was conducted in Beirut-Lebanon to evaluate the prevalence of HTN among marathon runners. The interview and the blood pressure measurements were done early in the morning before the race started. There is no published data on the Lebanese population on the prevalence of hypertension in this category of people. It was noted that as people get older the prevalence of hypertension increase. This is typical of other populations. We also observed that men had a higher chance to be hypertensive when compared to women in the same age group. The population that was studies represent a health population that perform regular training. However, there was a significant number of runners had hypertension and a significant number were unaware that they are hypertensive. In our study it was noticed that the $42 \mathrm{~km}$ runners were older and have higher BP but lower HR as compared to the $10 \mathrm{~km}$ runners. This is due to the fact that they are older; hence higher BP, but exercise on a regular basis, hence lowers HR.

Even though the $42 \mathrm{~km}$ runners had higher BP than the $10 \mathrm{~km}$ runners they tend to use less antihypertensive medications (16.7\% of $42 \mathrm{~km}$ runners vs. $19 \%$

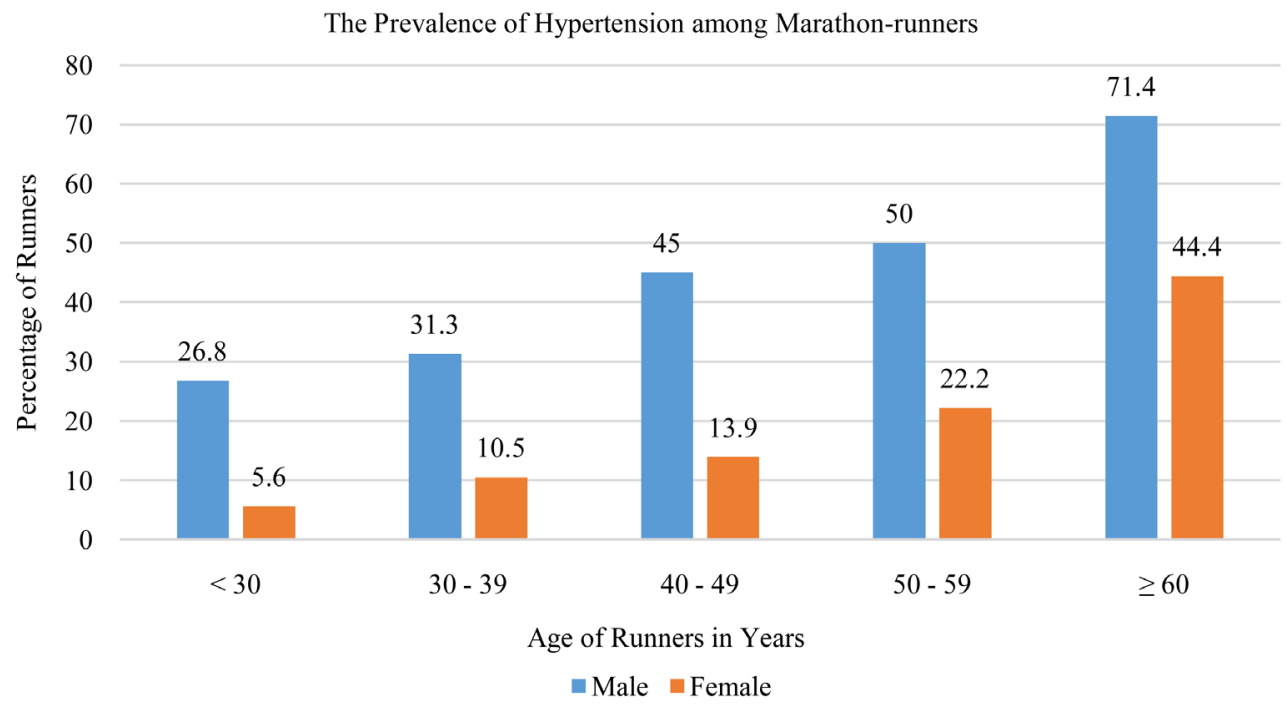

Figure 1. The prevalence of HTN defined as SBP $140 \mathrm{~mm} \mathrm{Hg}$ or DBP $90 \mathrm{~mm} \mathrm{Hg}$ according to age and gender among runners in Beirut-Marathon 2014. 
of the $10 \mathrm{~km}$ runner). This was similar to the study that was done by Williams P.T. who showed that the slower running males and females (determined from marathon finish times and reported $10 \mathrm{~km}$ performance) had greater use of hypertension and high cholesterol medications than did their faster running counterparts [11]. He showed that the prevalence of HTN, hyprecholesterolemia and DM decrease with the frequency of marathon participation independent of annual running distance [11]. Our study had showed that the $42 \mathrm{~km}$ runners had less history of DM and dyslipidemia than the $10 \mathrm{~km}$ runners even though the numbers were not statistically significant.

This is the first published data in our region. It reflects the importance of awareness for the prevalence of hypertension in this relatively active and health population. No studies were done on the prevalence of hypertension and other cardiovascular risk factors among marathon runners. Even though the numbers were small but is highlights the importance of awareness that is needed in this population.

\section{Limitations}

The study is an observational in a relatively small number of runners. The $42 \mathrm{~km}$ group was smaller than the $10 \mathrm{~km}$ group. Data only represents the Lebanese population. Risk factors assessment was only done through a questionnaire. However, the relatively limited data is essential to raise awareness for the Lebanese population and to conduct more elaborate studies in this age group.

\section{Conclusion}

There is a high prevalence of HTN among marathon runners but minorities were aware that they are hypertensive. The $42 \mathrm{~km}$ runners tend to be older with higher systolic blood pressure as compared to the $10 \mathrm{~km}$ runners. This study reflects the importance of raising awareness and conducting more elaborate clinical trials on this population.

\section{References}

[1] Lee, H.Y., Kim, J.H., Kim, B.O., et al. (2013) Regular Exercise Training Reduces Coronary Restenosis after Percutaneous Coronary Intervention in Patients with Acute Myocardial Infarction. International Journal of Cardiology, 167, 2617-2622. https://doi.org/10.1016/j.ijcard.2012.06.122

[2] Dunn, A.L., Marcus, B.H., Kampert, J.B., et al. (1997) Reduction in Cardiovascular Disease Risk Factors: 6-Month Results from Project Active. Preventive Medicine, 26, 883-892. https://doi.org/10.1006/pmed.1997.0218

[3] Lumb, A. (2014) Diabetes and Exercise. Clinical Medicine, 14, 673-676. https://doi.org/10.7861/clinmedicine.14-6-673

[4] Ruivo, J.A. and Alcântara, P. (2012) Hypertension and Exercise. Revista Portuguesa de Cardiologia, 31, 151-158. https://doi.org/10.1016/j.repc.2011.12.012

[5] Latimer-Cheung, A.E., Pilutti, L.A., Hicks, A.L., et al. (2013) Effects of Exercise Training on Fitness, Mobility, Fatigue, and Health-Related Quality of Life among 
Adults with Multiple Sclerosis: A Systematic Review to Inform Guideline Development. Archives of Physical Medicine and Rehabilitation, 94, 1800-1828.

https://doi.org/10.1016/j.apmr.2013.04.020

[6] Predel, H.G. (2014) Marathon Run: Cardiovascular Adaptation and Cardiovascular Risk. European Heart Journal, 35, 3091-3098.

https://doi.org/10.1093/eurheartj/eht502

[7] Kim, J.H., Malhotra, R., Chiampas, G., et al. (2012) Cardiac Arrest during LongDistance Running Races. Race Associated Cardiac Arrest Event Registry (RACER) Study Group. The New England Journal of Medicine, 366, 130-140. https://doi.org/10.1056/NEJMoa1106468

[8] Mathews, S.C., Narotsky, D.L., Bernholt, D.L., et al. (2012) Mortality among Marathon Runners in the United States, 2000-2009. The American Journal of Sports Medicine, 40, 1495-1500. https://doi.org/10.1177/0363546512444555

[9] National Heart Foundation of Australia's National Blood Pressure and Vascular Disease Advisory Committee (2008) Guide to Management of Hypertension 2008. http://www.heartfoundation.org.au/SiteCollectionDocuments/Guide-to-manageme nt-hypertension-2008.pdf

[10] Sharman, J.E. and Stowasser, M. (2009) Australian Association for Exercise and Sports Science Position Statement on Exercise and Hypertension. Journal of Science and Medicine in Sport, 12, 252-257. https://doi.org/10.1016/j.jsams.2008.10.009

[11] Williams, P.T. (2009) Lower Prevalence of Hypertension, Hypercholesterolemia, and Diabetes in Marathoners. Medicine \& Science in Sports \& Exercise, 41, 523-529. https://doi.org/10.1249/MSS.0b013e31818c1752

\section{List of Abbreviations}

$\begin{array}{ll}\text { BP } & \text { Blood pressure } \\ \text { BMI } & \text { Body mass index } \\ \text { CRF } & \text { Case report form } \\ \text { DM } & \text { Diabetes Mellitus } \\ \text { DBP } & \text { Diastolic blood pressure } \\ \text { ECG } & \text { Electrocardiogram } \\ \text { HTN } & \text { Hypertension } \\ \text { HR } & \text { Heart rate } \\ \text { NS } & \text { Not significant } \\ \text { SAS } & \text { Statistical analysis system } \\ \text { SBP } & \text { Systolic blood pressure }\end{array}$


Submit or recommend next manuscript to SCIRP and we will provide best service for you:

Accepting pre-submission inquiries through Email, Facebook, LinkedIn, Twitter, etc. A wide selection of journals (inclusive of 9 subjects, more than 200 journals)

Providing 24-hour high-quality service

User-friendly online submission system

Fair and swift peer-review system

Efficient typesetting and proofreading procedure

Display of the result of downloads and visits, as well as the number of cited articles Maximum dissemination of your research work

Submit your manuscript at: http://papersubmission.scirp.org/

Or contact ojepi@scirp.org 